\title{
College Student Learning Motivation in Online Learning in Jakarta During the COVID-19 Pandemic: A Descriptive Study
}

\author{
Angky Kenedi ${ }^{1}$ Niken Widi Astuti ${ }^{1 *}$ \\ ${ }^{1}$ Faculty of Psychology, Universitas Tarumanagara, West Jakarta 11440, Indonesia

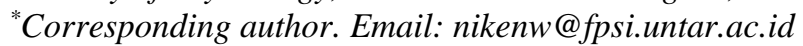

\begin{abstract}
Learning motivation is a form of encouragement that comes from within the individual by moving himself to learn, learning motivation comes from the basic theory of self-determination theory. Self-determination theory is a form of motivation and personality approach to see the resources owned by individuals who are always developing. College students in achieving learning goals are based on a motivational process. This study aims to determine the overview of college student learning motivation in online learning in Jakarta the during COVID-19 pandemic. This research was conducted with a total of 312 Jakarta student participants, namely 73 male and 239 female. This type of research is descriptive survey research, with quantitative methods. This research data collection technique with convenience sampling and snowball sampling. The measuring instrument used is the academic motivation scale by assessing seven dimensions using a Likert scale of 1 to 7 . The analysis in this study shows that the description of learning motivation can be said to be high, meaning that the learning motivation of Jakarta students is high, which is done by looking at the seven dimensions of learning motivation.
\end{abstract}

\section{Keywords: Learning motivation, self-determination theory, descriptive study}

\section{INTRODUCTION}

Technology that continues to develop with the development of industry 4.0 is called the industrial revolution 4.0 which has the goal of helping make it easier for humans to work, by implementing collaboration between humans and machines [1]. The emergence of the 4.0 industrial revolution was marked by 3D printing, artificial intelligence (AI), big data, and others to make human work easier [2]. The development of the industrial revolution 4.0 changes people's behavioral patterns, with changes in technology that can make life easier [3]. Technology develops in every aspect of life, such as education. Education is one of the aspects that the government is paying attention to, with the 12 years compulsory education.

Technology that continues to develop can help with learning methods. Learning methods are divided into two types, namely face-to-face learning methods and online learning methods. In the face-to-face learning method, a teacher can teach using a PowerPoint presentation assisted by a projector in displaying learning material in class. Technology also helps students in learning, such as seeking knowledge using the internet. Teachers are expected to be able to train their students to be able to use technology efficiently [3].
Learning methods in Indonesia use face to face. The faceto-face learning method has an interaction between the teacher and students, with the delivery and reception of two-way communication which is more effective because it involves all senses [4]. The learning environment is a factor in increasing the motivation of participants to learn with the support of a learning environment that supports the learning model [5]. Learning with face-to-face methods can increase the learning motivation of students with the interaction between teachers and students, a supportive physical environment, and a varied learning atmosphere that involves students to be active [6]. However, this face-to-face learning method was replaced, due to the widespread condition of coronavirus disease.

By 2020, the coronavirus disease or known as COVID-19 has spread widely throughout the world, as many as 203 countries have been affected [7]. WHO emphasizes that people need to use masks when traveling, and wash their hands and use hand sanitizers. The development of the spread of COVID-19 in Indonesia from data cases 11 September 2020 there were 210940 cases, data as of 12 November 2020 there were 452291 cases, data as of 11 December 2020 there were 605243 cases, and data per 18 January 2021 there were 907929 cases [8]. The COVID-19 cases that continue to spread and the number of cases have increased, prompting the Indonesian Government to issue lockdown or quarantine regulations, this is supported by 
the existence of large-scale social restrictions from the provincial government regulations imposed in Jakarta. The emergence of the large-scale social restrictions is expected to reduce the spread of covid-19 in the community [9].

The impact of COVID-19 changes the learning method that was initially face-to-face or met in class, then it has changed to distance learning which requires teaching staff to teach digitally [10]. In online learning, teachers have a demand to build the quality of learning that can run smoothly, such as creating a conducive learning atmosphere, presenting interesting material, which allows students to understand the material presented [11].

Students while taking online learning during the COVID19 pandemic experienced saturation, so that students became less active in class and did not get optimal learning outcomes [9]. Students experience boredom because of the many tasks given by the teacher [12]. In online learning students also become passive, less creative and productive, students also experience stress, and students get information that accumulates in learning due to fatigue in social media [13]. So, learning motivation is needed so that you can be enthusiastic about learning and interested in the learning that is being studied to get good learning achievement results [9].

Researchers conducted personal communication to support research topics by looking for phenomena in the field with 5 students who were taking online learning during the COVID-19 pandemic. The researcher conducted interviews with five students with the initials consisting of L, W, A, I, and LM. Based on interviews that have been conducted on five students, it can be seen that there is a decrease in learning motivation, which is caused by problems with an internet connection, lack of focus in learning, the emergence of boredom in learning, decreased desire to learn, and disturbances caused by family members (personal communication, 19 January 2021). So, in online learning, it is necessary to improve the quality of learning.

Low learning success is caused by low motivation [9]. In achieving learning goals, it is important to have motivation as an important thing [14]. Motivation to learn has a meaning as an impetus that moves him to achieve his goals in learning [15]. Motivation is divided into two categories, namely intrinsic motivation and extrinsic motivation. Intrinsic motivation is an energy that come from within the individual for his own goals which comes from his interests, needs and independence in learning [16]. Meanwhile, extrinsic motivation is an external push to achieve a goal, in the form of other people's factors, learning topics, and learning strategies created by the teacher [17]. In increasing achievement, such as the value or degree of students, it is more suitable with the extrinsic motivation that encourages student commitment [16].

Research by Fitriyani et al., based on the results of research conducted on the learning motivation of students majoring in education in online learning during the COVID-19 pandemic showed a result of $80.27 \%$ as a very good criterion at the University of Kuningan in West Java [10]. Students can have high learning motivation in online learning, even in a state of the COVID-19 pandemic.
Based on previous research on learning motivation. Thus, researchers are interested in researching students who are more general in research in Jakarta, which is supported by the existence of adequate digital technology for online learning. To get an overview of college student learning motivation in online learning in Jakarta during the COVID-19 pandemic.

\section{BACKGROUND}

\subsection{Learning Motivation}

According to Ryan and Deci self-determination theory (SDT) is an approach to motivation and personality that uses empirical methods to see the importance of human resources that continue to develop in personality and selfregulation [18]. Ryan and Deci state that the relationship of self-determination with development, behavior, performance and well-being is based on a motivational process [19].

According to [17] learning motivation is an inner drive that directs him to learn. Motivation to learn is a form of inner and outer encouragement that moves things inside and outside oneself to achieve their goals in the learning process [15].

Motivation to learn is a condition that is in someone who has an encouragement that provides enthusiasm and direction to achieve learning goals [14]. The process of internal motivation in providing energy and direction to behavior, and includes goals, beliefs, perceptions, and expectations [20].

\subsubsection{Dimensions of academic motivation}

According to Vallerand et al., there are three types of motivation, namely intrinsic motivation, extrinsic motivation, and amotivation based on the selfdetermination theory initiated by Deci and Ryan [21]. Intrinsic motivation is an energy that exists within a person, by carrying out an activity for his own sake, and the pleasure and satisfaction obtained by participating in these activities [16][21]. Extrinsic motivation is a form of behavior that is based on goals for certain consequences and not for its interests, such as avoiding punishment, social acceptance, or achievement [21][22]. Amotivation is an individual who lacks intrinsic and extrinsic motivation [23].

Intrinsic motivation is divided into three types based on the tripartite taxonomy that has been studied independently, namely intrinsic motivation to know, intrinsic motivation toward accomplishment, and intrinsic motivation to experience stimulation [21]. Intrinsic motivation to know is a fact in carrying out an activity for pleasure and satisfaction experienced during learning, exploring, and trying to understand something new. Intrinsic motivation toward accomplishment a fact involved in an activity to achieve or create something. Intrinsic motivation to experience stimulation is when 
someone does an activity to experience a sensation of stimulation that comes from the activity undertaken [21]. Extrinsic motivation is divided into three types found by Deci et al. These can be ordered from low to high, namely identified regulation, introjected regulation, and external regulation [21]. Identified regulation is a form of someone's situation in behaving to be appreciated and considered important for individuals when achieving their goals. Introjected regulation as a form of individual begins to understand a reason in his actions. External regulation is a form of behavior that is regulated through external means such as gifts and obtaining freedom [21].

\section{METHODS}

This type of research is quantitative, with a descriptive survey method. Researchers got 312 study participants. The characteristics of the participants in this study were (a) active students, (b) students aged 17-25 years, (c) male or female, (d) students studying domicile in Jakarta, and (e) students studying with online learning methods or elearning or in a network (online). The sampling technique used was convenience sampling and snowball sampling to obtain research participant data

The measuring instrument used is the academic motivation scale (AMS) questionnaire, which is divided into seven dimensions, namely, intrinsic motivation to know, intrinsic motivation toward accomplishment, intrinsic motivation to experience stimulation, identified regulation, introjected regulation, external regulation, and amotivation. Each dimension consists of 4 statement items for a total of 28 items. An academic motivation scale measuring instrument developed by Vallerand et al. with the basic theory of selfdetermination theory initiated by Deci and Ryan [21]. This scale was adapted into Indonesian by Marvianto and Widhiarso [22]. Researchers get a reliability test that can be said to be good ( $\alpha=0.74$ to 0.90$)$.

\section{FINDINGS AND DISCUSSIONS}

Table 1 The frequency of learning motivation categories based on the academic motivation scale (AMS)

\begin{tabular}{lrrrrrrrrrrrrrr}
\multirow{2}{*}{ Categories } & \multicolumn{2}{c}{ IMTK } & \multicolumn{2}{c}{ IMTA } & \multicolumn{2}{c}{ IMTE } & \multicolumn{2}{c}{ IR } & \multicolumn{2}{c}{ INR } & \multicolumn{2}{c}{ ER } & \multicolumn{1}{c}{ AMO } \\
& \multicolumn{1}{r}{} & \multicolumn{1}{c}{$\%$} & \multicolumn{1}{c}{$\mathrm{n}$} & \multicolumn{1}{c}{$\%$} & \multicolumn{1}{c}{$\mathrm{n}$} & \multicolumn{1}{c}{$\%$} & \multicolumn{1}{c}{$\mathrm{n}$} & $\%$ & \multicolumn{1}{c}{$\mathrm{n}$} & $\%$ & $\mathrm{n}$ & $\%$ & \multicolumn{1}{c}{$\mathrm{n}$} & \multicolumn{1}{c}{$\%$} \\
\hline Low & 2 & 0.6 & 1 & 0.3 & 12 & 3.8 & 10 & 3.2 & 5 & 1.6 & 2 & 0.6 & 210 & 67.3 \\
Medium & 51 & 16.3 & 43 & 13.8 & 129 & 41.3 & 79 & 25.3 & 77 & 24.7 & 51 & 16.3 & 70 & 22.4 \\
High & 259 & 83 & 268 & 85.9 & 171 & 54.8 & 223 & 71.5 & 230 & 73.7 & 259 & 83 & 32 & 10.3 \\
Total & 312 & 100 & 312 & 100 & 312 & 100 & 312 & 100 & 312 & 100 & 312 & 100 & 312 & 100 \\
\hline
\end{tabular}

Description:

IMTK : Intrinsic motivation to know

IMTA : Intrinsic motivation toward accomplishment

IMTE : Intrinsic motivation to experience stimulation

IR : Identified regulation

INR : Introjected regulation

ER : External regulation

AMO : Amotivation

Students who have high learning motivation can be seen based on categorization indicators. The results of the analysis conducted showed that learning motivation based on the dimensions of intrinsic motivation to know, intrinsic motivation toward accomplishment, intrinsic motivation to experience stimulation, identified regulation, introjected regulation, and external regulation were in the high category. Meanwhile, learning motivation based on the amotivation dimension is in the low category.

This is in line with previous research conducted by Fitriyani et al. that students majoring in education at Kuningan University in the West Java area students have very good motivation to learn [10]. In the dimensions of learning motivation, intrinsic motivation to know, intrinsic motivation toward accomplishment, intrinsic motivation to experience stimulation, identified regulation, introjected regulation, and external regulation have high categories, it can be seen that the students have high learning motivation, supported by the amotivation dimension which has meaning has no motivation, and students in the motivation dimension are in the low category. So it can be said that the motivation to learn students in this study can be said to be high.

Motivation to learn is needed in students, the findings of this study found that the dimension of intrinsic motivation toward accomplishment is the dimension that has the highest number of participants in the high category, with an understanding of the satisfaction and pleasure experienced by individuals doing new things [22]. This is because the online learning method is new for students who are familiar with face-to-face learning methods. With Sianturi and Lisum research evaluation regarding learning motivation by finding that online learning methods for students become an interesting learning process [24]. 
Table 2 Different Test of Learning Motivation Based on Gender

\begin{tabular}{|c|c|c|c|c|c|c|}
\hline Dimension & Gender & $\mathbf{n}$ & Mdn & $\mathbf{Z}$ & $p$ & Difference \\
\hline \multirow{2}{*}{$\begin{array}{l}\text { Intrinsic Motivation to } \\
\text { Know }\end{array}$} & Male & 73 & 24 & \multirow{2}{*}{-0.417} & \multirow{2}{*}{0.677} & \multirow{2}{*}{ No significant differences } \\
\hline & Female & 239 & 24 & & & \\
\hline \multirow{2}{*}{$\begin{array}{l}\text { Intrinsic Motivation } \\
\text { toward Accomplishment }\end{array}$} & Male & 73 & 24 & \multirow{2}{*}{-1.491} & \multirow{2}{*}{0.136} & \multirow{2}{*}{ No significant differences } \\
\hline & Female & 239 & 24 & & & \\
\hline \multirow{2}{*}{$\begin{array}{l}\text { Intrinsic Motivation to } \\
\text { Experience Stimulation }\end{array}$} & Male & 73 & 21 & \multirow{2}{*}{-0.129} & \multirow{2}{*}{0.898} & \multirow{2}{*}{ No significant differences } \\
\hline & Female & 239 & 21 & & & \\
\hline \multirow{2}{*}{ Identified Regulation } & Male & 73 & 22 & \multirow{2}{*}{-2.12} & \multirow{2}{*}{0.034} & \multirow{2}{*}{ Significant differences } \\
\hline & Female & 239 & 24 & & & \\
\hline \multirow{2}{*}{ Introjected Regulation } & Male & 73 & 24 & \multirow{2}{*}{-1.85} & \multirow{2}{*}{0.064} & \multirow{2}{*}{ No significant differences } \\
\hline & Female & 239 & 24 & & & \\
\hline \multirow{2}{*}{ External Regulation } & Male & 73 & 24 & \multirow{2}{*}{-1.395} & \multirow{2}{*}{0.163} & \multirow{2}{*}{ No significant differences } \\
\hline & Female & 239 & 24 & & & \\
\hline \multirow{2}{*}{ Amotivation } & Male & 73 & 12 & \multirow{2}{*}{-4.002} & \multirow{2}{*}{0.000} & \multirow{2}{*}{ Significant differences } \\
\hline & Female & 239 & 8 & & & \\
\hline
\end{tabular}

Based on Table 2 it can be seen that the difference test analysis in learning motivation based on gender is seen in each dimension of learning motivation. First, the results of the analysis of the dimensions of intrinsic motivation to know show that the difference between men $(\mathrm{Mdn}=24)$ is the same or there is no difference with women $(\mathrm{Mdn}=24)$ which is not significant; $U($ male $=73$, female $=239)=$ 8444.5, $\mathrm{z}=-0.417, \mathrm{p}=0.677$.

Second, the results of the analysis of the dimensions of the intrinsic motivation toward accomplishment showed that the difference between men $(\operatorname{Mdn}=24)$ is the same or there is no difference with women $(\mathrm{Mdn}=24)$ which is not significant; $\mathrm{U}($ male $=73$, female $=239)=7724.5, \mathrm{z}=$ $-1.491, p=0.136$. Third, the results of the analysis of the dimensions of intrinsic motivation to experience stimulation show that male differences $(\mathrm{Mdn}=21)$ is the same or there is no difference with women $(\mathrm{Mdn}=21)$ which is not significant; $U($ male $=73$, female $=239)=$ $8637, \mathrm{z}=-0.129, \mathrm{p}=0.898$.

Fourth, the results of the dimension analysis identified regulation showed that men $(\mathrm{Mdn}=22)$ were significantly lower than women $(\mathrm{Mdn}=24)$; $\mathrm{U}$ (male $=73$, female $=$ $239)=7299, z=-2.120, p=0.034$. Fifth, the results of the analysis of the dimensions of introjected regulation showed that men $(\mathrm{Mdn}=22)$ are not significantly lower than women $(\mathrm{Mdn}=24)$; $\mathrm{U}($ male $=73$, female $=239)=$ $7480.5, \mathrm{z}=-1,850, \mathrm{p}=0.064$.

Sixth, the analysis of the dimensions of external regulation showed that men $(\mathrm{Mdn}=24)$ were not significantly different from women $(\mathrm{Mdn}=24)$; $\mathrm{U}($ male $=73$, female $=$ 239) $=7787.5, z=-1.395, p=0.163$. Seventh, the results of the analysis of the dimension of amotivation show that men $(\mathrm{Mdn}=12)$ are significantly higher than women $(\mathrm{Mdn}=8) ; \mathrm{U}($ male $=73$, female $=239)=6031.5, \mathrm{z}=$ 4.002, $\mathrm{p}=0.000$

Based on the research results, it was found that the learning motivation of men and women can be said to be high. However, by conducting a different test between men's and women's learning motivation. It was found that the male learning motivation was lower than the female learning motivation based on the dimensions of identified regulation, introjected regulation, and amotivation. This finding is supported by research by Malini and Fridari, which shows that women have a higher motivation than men, several factors might influence such as, women are easier to understand verbally, while men are easier to understand the material visually and skills, related to motoric [25]. In online lectures, the learning that is carried out is in the form of presentations as well as explaining the discussion, so that visual movements rarely appear which makes men may not be motivated compared to women.

\section{CONCLUSIONS}

The results of the descriptive analysis conducted on 312 student participants indicated that the learning motivation variable was high. This is illustrated by the high categorization for six dimensions of learning motivation such as intrinsic motivation to know, intrinsic motivation toward accomplishment, intrinsic motivation to experience stimulation, identified regulation, introjected regulation, and external regulation. The amotivation dimension is categorized as low, which can be said that students have 
high motivation. So it can be concluded that students have high learning motivation.

The limitation of the research experienced is cannot collect data directly. Taking data is not evenly distributed and for some explanations, it is less representative. In addition, researchers also did not examine the part of the number of semesters students have studied, which is less able to describe the students in each semester. Furthermore, the measuring instruments used have not been adapted in the situation during the COVID-19 pandemic.

It is hoped that further research can also see a broader picture related to learning motivation in online learning by looking at online learning factors with practicum or learning theory, and can add data from overseas or nonoverseas students. Future research can also see learning motivation based on semester can add more other information. It is hoped that further research can add several variables about the needs or other variables related to students or teachers. It is hoped that further research can adapt the measuring instruments used in the COVID-19 pandemic situation or according to the environmental conditions that are happening.

\section{ACKNOWLEDGMENT}

This study is supported by Faculty of Psychology, Universitas Tarumanagara, West Jakarta, Indonesia and Ms. Meylisa Permata Sari.

\section{REFERENCES}

[1] Y. Yin, S. Qin, A smart performance measurement approach for collaborative design in Industry 4.0. Advances in Mechanical Engineering, 11(1), (2019) 115. https://doi.org/10.1177\%2F1687814018822570

[2] H. Tinmaz, J. H. Lee. A preliminary analysis on Korean University students' readiness level for Industry 4.0 revolution. Participatory Educational Research (PER), 6(1) (2019) 70-83. https://doi.org/http://dx.doi. org/10.17275/per.19.6.6.1

[3] A. Sarıçoban, I. Tosuncuoğlu, Ö. Kırmizi, A technological Pedagogical Content Knowledge (TPACK) Assessment of Preservice EFL Teachers Learning to Teach English as a Foreign Language. Journal of Language and Linguistic Studies, 15(3), (2019) 1122-1138. https://doi.org/10.17263/jlls. 631552.

[4] A. Himawan, F. Nodia, Kelebihan metode tatap muka dalam menguasai Bahasa Inggris. Suara.com, 16Jun-2017. https://www.suara.com/health/2017/06/16/ 074046/kelebihan-metode-tatap-muka-dalammenguasai-bahasa-inggris?page $=2$

[5] A. Anggrawan, Analisis Deskriptif Hasil Belajar Pembelajaran Tatap Muka dan Pembelajaran Online Menurut Gaya Belajar Mahasiswa. MATRIK: Jurnal Manajemen, Teknik Informatika Dan Rekayasa Komputer. 18(2) (2019) 339-346. https://doi.org/https:// doi.org/10.30812/matrik.v18i2.411

[6] Minsih. \& A. G. D. Peran guru dalam pengelolaan kelas, Profesi Pendidikan Dasar, 5(1) (2018) 20 - 27. https://doi.org/10.23917/ppd.v1i1.6144

[7] A. N. Aslamah, Tantangan dan peluang pembelajaran jarak jauh bagi mahasiswa. Suara.com, 7Apr-2020, https://www.suara.com/yoursay/2020/04/07/ 104610/tantangan-dan-peluang-pembelajaran-jarakjauh-bagi-mahasiswa

[8] Komite Penanganan COVID-19 dan Pemulihan Ekonomi Nasional (KPCPEN). Peta sebaran COVID19. 2021. https://covid19.go.id/peta-sebaran-covid19

[9] Ferismayanti. Meningkatkan motivasi belajar siswa pada pembelajaran online akibat pandemi covid-19. LPMP Lampung, kemdikbud, 2020, May 29. https://lpmplampung.kemdikbud.go.id/detailpost/menin gkatkan-motivasi-belajar-siswa-pada-pembelajaranonline-akibat-pandemi-covid-19

[10] Y. Fitriyani, I. Fauzi, M. Z. Sari, Motivasi belajar mahasiswa pada pembelajaran daring selama pandemik covid-19. Jurnal Kependidikan, 6(2) (2020) 165-175. http://ojs.ikipmataram.ac.id/index.php/jurnalkependidik an/article/view/2654

[11] A. Cahyani, I. D. Listiana, S. P. D. Larasati, Motivasi belajar siswa SMA pada pembelajaran daring di masa pandemi covid-19. IQ (Ilmu Al-qur'an): Jurnal Pendidikan Islam. 3(1) (2020) 123-140. https://doi.org/ 10.37542/iq.v3i01.57

[12] A. Rofiq, Atasi kejenuhan belajar daring, mahasiswa PKM Unisba ajak anak-anak menggambar poster. Jatim TIMES, 16-Sep-2020. https://jatimtimes. com/baca/223842/20200916/151200/atasi-kejenuhanbelajar-daring-mahasiswa-pkm-unisba-ajak-anak-anakmenggambar-poster

[13] N. B. Argaheni, Sistematik review: Dampak perkuliahan daring saat pandemi COVID-19 terhadap mahasiswa Indonesia. Placentum: Jurnal Ilmiah Kesehatan dan Aplikasinya. 8(2) (2020) 99-108. https://jurnal.uns.ac.id/placentum/article/download/430 $08 / 28002$ 
[14] A. Emda, Kedudukan motivasi belajar siswa dalam pembelajaran. Lantanida Journal. 5(2) (2017) 172-182. https://jurnal.ar-raniry.ac.id/index.php/lantanida/article/ download/2838/2064

[15] A. Muis, Pengaruh motivasi belajar dan kinerja guru terhadap prestasi belajar siswa pada Sekolah Menengah Atas Negeri 16 Jakarta. Jurnal Bijak, 11(1) (2014). https://adoc.pub/pengaruh-motivasi-belajar-dan -kinerja-guru-terhadap-prestasi.html

[16] K. Selvi, Motivating Factors in Online Courses. Procedia - Social and Behavioral Sciences, 2(2) (2010) 819-824. https://doi.org/10.1016/j.sbspro.2010.03.110

[17] J. W. Santrock, Educational psychology (5th ed.). New York: McGraw-Hill. 2011.

[18] R. M. Ryan, E. L. Deci, Self-determination theory and the facilitation of intrinsic motivation, social development, and well-being. American Psychologist, 55(1) (2000) 68-78. https://doi.apa.org/doi/10.1037/ 0003-066X.55.1.68

[19] R. M. Ryan, E. L. Deci, Self-determination theory: Basic psychological needs in motivation, development, and wellness. Guilford Press. 2017.

[20] M. H. Dembo, Motivation and Learning Strategies for College Success: A Self-Management Approach (2nd ed.). Mahwah, NJ: Lawrence Erlbaum Associates. 2004.

[21] R. J. Vallerand, L. G. Pelletier, M. R. Blais, N. M. Briere, C. Senecal, E. F. Vallieres, The academic motivation scale: A measure of intrinsic, extrinsic, and amotivation in education. Educational and Psychological Measurement, 52(4) (1992) 1003-1017. https://www.researchgate.net/publication/209836138_T he_Academic_Motivation_Scale_A_Measure_of_Intrin sic_Extrinsic_and_Amotivation_in_Education

[22] R. D. Marvianto, W. Widhiarso, Adaptasi academic motivation scale (AMS) versi Bahasa Indonesia. Gadjah Mada Journal of Psychology, 4(1) (2018) 87-95. https://jurnal.ugm.ac.id/gamajop/article/ view/45785/24479

[23] R. J. Vallerand, L. G. Pelletier, M. R. Blais, N. M. Briere, C. Senecal, E. F. Vallieres, On the assessment of intrinsic, extrinsic, and amotivation in education: Evidence on the concurrent and construct validity of the academic motivation scale. Educational and Psychological Measurement, 53(1), (1993) 159-172. https://doi.org/10.1177\%2F0013164493053001018
[24] S. R. Sianturi, K. Lisum, Peningkatan motivasi belajar melalui evaluasi e-learning pada Institusi Keperawatan di Jakarta dan Depok. Jurnal Pendidikan Keperawatan Indonesia, 4(2) (2018) 122-130. https:// ejournal.upi.edu/index.php/JPKI/article/view/11563

[25] G. A. N. D. Malini, I. G. A. D. Fridari, Perbedaan motivasi belajar siswa ditinjau dari jenis kelamin dan urutan kelahiran di SMAN 1 Tabanan dengan sistem full day school. Jurnal Psikologi Udayana. (2019) 145155. https://ojs.unud.ac.id/index.php/psikologi/article/ view/52513/31041 